\title{
EMPHYSEMATOUS CYSTITIS: CASE REPORT
}

Daniel Perez Fentes, Miguel Blanco Parra, Jose Lema Grille, Valentin Toucedo Caamaño, Serafin Novas Castro, Pedro Lamas Cedron and Manuel Villar Nuñez.

Urology Service. Complejo Hospitalario Universitario de Santiago de Compostela. Santiago de Compostela. Spain.

Summary.- OBJECTIVE: To report one case of emphysematous cystitis and to review its diagnosis and treatment in the related literature.

METHOD: We report the case of a type II diabetic 91-yearold woman with jaundice, hematuria, vomits, abdominal pain and poor glycemia control. Diagnosis was obtained by plain abdominal X-ray and ultrasonography, and confirmed by CT. E.coli was isolated in urinary culture.

Daniel Adolfo Pérez Fentes

Servicio de Urología

Hospital Clínico Universitario de Santiago de Compostela.

Travesía Choupana s/n. (Spain)

15706. Santiago de Compostela.

danielfentes@yahoo.es

Accepted for publication: May 26th 2008. 
RESULTS: Antibiotic intravenous therapy with piperacillin-tazobactam, urinary bladder catheterization and strict glycemia control. The patient was discharged from hospital on day 5, with 14 additional days of orally administered amoxicillinclavulanic and bladder catheterization. Complete clinical, radiologic and microbiologic resolution was achieved.

CONCLUSIONS: Emphysematous cystitis is a rare entity, most common in diabetic women, which results from infection of the urinary bladder with gas-producing pathogens, mainly E.coli. Clinical presentation is variable. Emphysematous cystitis can be diagnosed radiologically, mainly with CT scan. The management consists of broad-spectrum antibiotics, strict glycemic control and bladder drainage. Emphysema-tous cystitis usually has a benign course, but complications may arise in up to $10-20 \%$ of cases, requiring surgical treat-ment.

Keywords: Emphysematous cystitis. Diagnosis. Treatment.

Resumen.- OBJETIVO: Presentar un caso de cistitis enfisematosa y revisar aspectos diagnósticos y terapéuticos en la literatura relacionada.

MÉTODO: Presentamos el caso de una mujer de 91 años, diabética tipo II, con ictericia, hematuria, vómitos, dolor abdominal y mal control glucémico. El diagnóstico inicial fue mediante radiografía simple de abdomen y ecografía abdominal, luego confirmado con TC. Urocultivo positivo para Escherichia coli.

RESULTADOS: Tratamiento antibiótico intravenoso con piperacilina-tazobactam, sondaje vesical y control estricto de las glucemias. Alta hospitalaria a los 5 días con sonda urinaria y tratamiento antibiótico vía oral durante 14 días con amoxicilina-clavulánico. Completa resolución clínica, radiológica y microbiológica del cuadro.

CONCLUSIONES: La cistitis enfisematosa es una entidad poco frecuente, típica de mujeres diabéticas, producida por microorganismos productores de gas, principalmente E.coli. Su presentación clínica es variable. El diagnóstico generalmente se realiza por métodos de imagen, fundamentalmente TC. El tratamiento consiste en drenaje vesical, estricto control glucémico y antibioterapia de amplio espectro. El pronóstico suele ser favorable, salvo en un 10-20\% de los casos, en los que se requiere intervención quirúrgica.

Palabras clave: Cistitis enfisematosa. Diagnóstico. Tratamiento.

\section{INTRODUCTION}

Emphysematous cystitis (EC) is a rare complication of the lower urinary tract. It is defined by the presence of gas in the bladder wall and often in the bladder lumen.

Of variable clinical presentation, it is typically found in middle-aged diabetic women, and generally caused by gas-forming microorganisms. It may sometimes be associated with other risk factors such as recurrent urinary tract infections, indwelling bladder catheter, neurogenic bladder or bladder outlet obstruction.

We report a case of emphysematous cystitis, describing its clinical characteristics, the diagnostic tests used and treatment instituted to compare them with the existing literature and finally to discuss the current ideal approach to this condition.

\section{CASE REPORT}

We report the case of a 91-year-old type 2 diabetic woman on oral hypoglycemic treatment, hypertensive and dependent for physical activities of daily living after an ischemic stroke. The family reported that the patient has suffered vomiting, hypogastric pain and hematuria in the past 15 days. Initially treated with phosphomycin-trometamol on an outpatient basis, her condition worsened in the past 48 hours with the appearance of jaundice and generalized abdominal pain, as a result of which she came to the emergency department.

The patient was conscious, oriented, afebrile and normotensive. Physical examination revealed the presence of jaundice and abdominal pain in the hypogastrium and right hypochondrium on deep palpation, without evidence of associated peritoneal irritation.

Biochemistry tests showed poor glycemic control Iglucose: $10.9 \mathrm{mg} / \mathrm{dL}$; direct bilirubin: $9.3 \mathrm{mg} / \mathrm{dL}$; GOT: 57 U/L; GPT: 134 U/L; GGT: 806 U/L; alkaline phosphatase: $657 \mathrm{U} / \mathrm{L}$ ) and acute renal insufficiency (creatinine: $2.8 \mathrm{mg} / \mathrm{dL}$ ). The complete blood count was practically normal (white cell count: $11,990 / \mathrm{mm}^{3}$ with $75.9 \%$ neutrophils; hemoglobin: $15.5 \mathrm{~g} / \mathrm{dL}$; platelets: $217,000 /$ $\left.\mathrm{mm}^{3}\right)$. Routine urine analysis demonstrated the presence of glycosuria and microhematuria and was nitrate negative. Sediment was clearly pathological, showing abundant white cells and germs.

As complementary tests, a plain abdominal X-ray was performed, which revealed the presence of ectopic air in the lesser pelvis, probably in the bladder wall, suggestive of emphysematous cystitis (Figure 1), and an abdominal ultrasonography, which confirmed the presence of gas bordering the bladder wall. It also revealed a marked dilation of the gallbladder and intra and extrahepatic bile ducts suspicious of choledocolithiasis. The urine culture grew more than 100,000 CFU/ml of Escherichia coli 
sensitive to amoxicillin-clavulanate, cefuroxime-axetyl, cefotaxime, piperacillin-tazobactam, gentamycin and trimethoprim-sulfamethoxazole.

With diagnoses of obstructive jaundice and emphysematous cystitis, it was decided to admit the patient. Initial treatment consisted of intravenous antibiotic therapy with piperacillin-tazobactam, urinary bladder catheterization and strict glycemic control. An abdomino-pelvic CT scan was requested that confirmed the diagnosis of emphysematous cystitis (Figure 2). Obstructive jaundice was resolved after performing endoscopic retrograde cholangiopancreatography and sphinterotomy, and no bile duct calculi or dilatation were found on the followup ultrasound.

After 5 days of intravenous antibiotic therapy, her general condition was good and she was discharged from the hospital under oral antibiotic treatment with amoxicillin-clavulanate for 14 days, while leaving in place the urinary catheter. The follow-up urine culture after treatment was negative. The follow-up abdomino-pelvic CT scan did not show residual lesions.

\section{DISCUSSION}

Emphysematous cystitis (EC) is a rare clinico-pathological entity. Since this condition was first described by Einsenlhor in 1888 and defined precisely by Bailey in 1961, only about 200 cases have been published in the world medical literature $(1,2)$. Its incidence has increased in recent years due to the development and routine use of diagnostic imaging methods.

EC is defined as a collection of gas within the bladder wall secondary to an infectious cause, which may or may not be associated with intraluminal gas. Therefore, the presence of gas within the urinary tract (pneumatu-

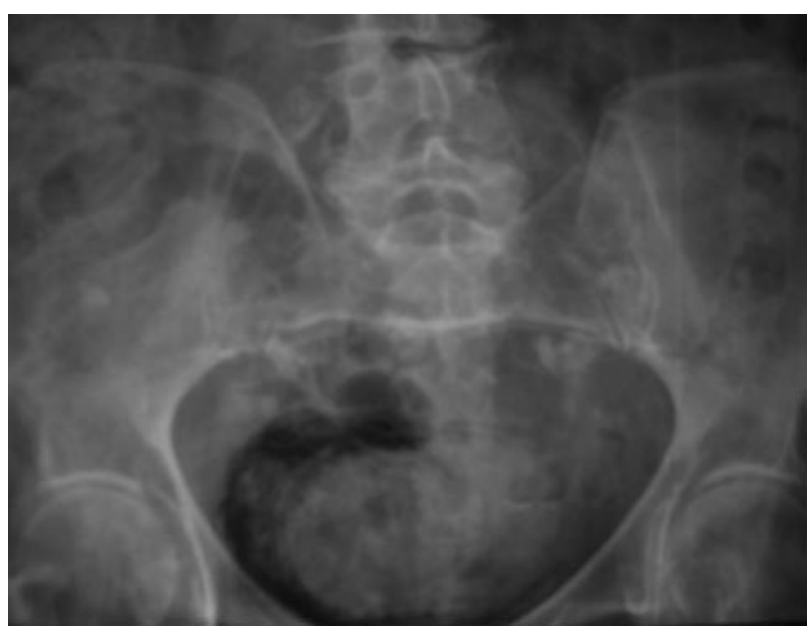

FIGURE 1. Plain abdominal X-ray. ria) is not sufficient to define EC, and indeed only $27 \%$ of patients with CE present in this way $(1,3)$.

EC occurs more commonly in women (64\%), generally in the sixth to seventh decade of life, and in diabetic patients $(66 \%)(1,3)$. Other risk factors for patients are recurrent urinary tract infections, neurogenic bladder, indwelling bladder catheter, bladder outlet obstruction, bladder diverticula, history of malignant hematological disease and immunocompromised patients (4-6).

$\mathrm{CE}$ is caused by gas-forming microorganisms, mainly Escherichia coli $(58 \%)$, followed by Klebsiella pneumoniae. Other commonly isolated pathogens are Enterococcus, fungi from genus Candida, and anaerobic germs such as Clostridium perfringens $(1,3,7)$. There are several theories on the pathogenesis of this condition, but its exact mechanism is still unclear. It is thought that the presence of gas-forming germs, a high tissue glucose concentration, and poor tissue perfusion favor its development. In diabetic patients (especially if they are poor controlled), the high glucose concentration within the tissues acts as a substrate for these microorganisms to produce $\mathrm{CO}_{2}$ through different fermentation processes. In the third of cases of EC occurring in nondiabetic patients, it is thought that these pathogens use urinary lactose or tissue proteins for gas production $(1-3,6,8)$.

The clinical presentation of EC is nonspecific and ranges from the absence of symptoms to septic shock. The most common form of presentation is abdominal pain (80\%), followed by lower urinary tract symptoms, both during bladder filling and emptying. The presence of hematuria is more common in the usual form of bacterial cystitis $(1-, 3)$.

As the clinical features are nonspecific, the diagnosis of EC is usually established using imaging techniques. A plain abdominal X-ray may be useful, showing a

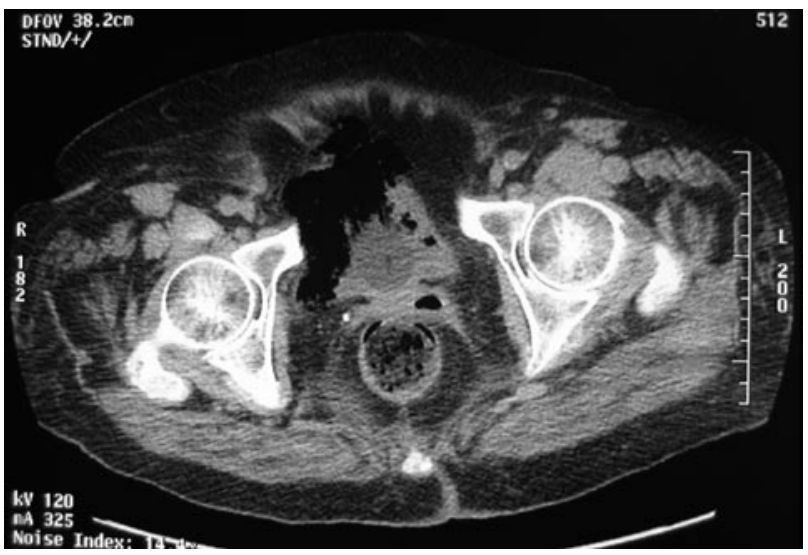

FIGURE 2. Abdomino-pelvic CT scan. 
radiolucent curvilinear area delineating the urinary bladder, with or without intraluminal air. Ultrasound shows bladder wall thickening with marked echogenicity, but its diagnostic sensitivity is low. The most valuable imaging test for the diagnosis of emphysematous cystitis is the abdomino-pelvic CT scan, which allows early detection of the presence of intramural gas in the urinary bladder as well as determining the extent and severity of the disease $(9,10)$. CT also allows differential diagnosis to be performed against other pathological conditions in which gas may be present in the pelvis, such as enterovesical or vesicovaginal fistula, pneumatosis cystoides intestinalis, emphysematous vaginitis or gas gangrene in the uterus. If a vesicocolic or vesicovaginal fistula is suspected, it is recommended to complement CT with CT cystography (11). Cystoscopic examination is not essential for diagnosis.

Like any patient with diabetes mellitus, patients with emphysematous cystitis should have a microbiological study of urine before the start and after the end of treatment, to confirm eradication of the germ (12).

Management of EC consists of strict glycemic control, bladder drainage and broad-spectrum antibiotics. The use of hyperbaric oxygen or intravesical irrigation with amikacin are not standard therapeutic approaches, but have been associated with clinical improvement in some cases $(8,13)$.

Once the acute phase has resolved, antibiotic treatment should be adjusted according the result of the urine culture, giving preference to the oral route. Treatment duration is not clear, but short courses of treatment are not advised (14). After resolution of the acute phase, those risk factors for the development of EC that are reversible should also be corrected.

The prognosis of emphysematous cystitis is generally favorable. However, complications may arise in 10$20 \%$ of cases, such as emphysematous pyelonephritis, bladder perforation $(2,8)$ and sepsis, requiring surgical treatment. Nevertheless, the death rate of emphysematous cystitis is low $(7 \%)$ compared to emphysematous conditions in other locations $(1,3)$.

\section{CONCLUSIONS}

1. Emphysematous cystitis is defined as the presence of gas within the bladder wall secondary to an infectious cause, which may or may not be associated with intraluminal gas.

2. The pathogenesis of emphysematous cystitis is unknown, but it is probably due to a multifactorial mechanism. The most commonly isolated germ is Escherichia coli.
3. The clinical features of emphysematous cystitis are nonspecific, and therefore its diagnosis is made using imaging tests, mainly CT.

4. Management consists of adequate glycemic control, bladder drainage and intravenous antibiotic therapy.

5. The prognosis is generally good, except in $10-20 \%$ of cases, in which surgical treatment is required because of the occurrence of complications.

\section{REFERENCES AND RECOMENDED READINGS ("of special interest, ${ }^{* *}$ of outstanding interest)}

**1. Thomas AA, Lane BR, Thomas AZ, Remer EM, Campbell SC, Schoskes DA. Emphysematous cystitis: a review of 135 cases. BJU Int, 2007; 100 (1): 17-20.

2. Bañón VJ, García JA, Valdelvira P, et al. Perforación vesical intraperitoneal en el transcurso de una cistitis enfisematosa. Actas Urol Esp, 2000; 24 (6): 501-503.

**3. Grupper M, Kravtsov A, Potasman I. Emphysematous Cystitis: illustrative case report and review of the literatura. Medicine (Baltimore), 2007; 86 (1): 47-53.

4. Juan YS, Chuang SM, Shen JT, et al. Unusual gas pattern in emphysematous cystitis: a case report. Kaohsiung J Med Sci, 2005; 21 (1): 44-47.

5. Nemati E, Basra R, Fernandes J, Levy JB. Emphysematous cistitis. Nephrol Dial Transplant, 2005; 20 (3): 652-653.

6. Sanchez I, Kessler P, Odriozola M. Cistitis enfisematosa. An Med Interna, 2006; 23 (12): 602-603.

7. Perlemoine C, Neau D, Gin H, Sahnoun A, Pariente JL, Rigalleau V. Emphysematous cystitis. Diabetes Metab, 2004; 30 (4): 377-379.

8. Bracq A, Fourmarier M, Bourgninaud O, et al. Cystite emphysémateuse compliquée de perforation vésicale: diagnostic et traitement d'une observation rare. Prog Urol, 2004; 14 (1): 87-89.

9. Leclercq $\mathrm{P}$, Hanssen $\mathrm{M}$, Borgoens $\mathrm{P}$, Bruyère $\mathrm{PJ}$, Lancellotti P. Emphysematous cystitis. CMAJ, 2008; 178 (7): 836.

10. Takeshita T, Shima H, Oishi S, Machida N, Uchiyama K. Emphysematous Cystitis. Intern Med, 2004; 43 (8): 761-762.

*11. Grayson DE, Abbott RM, Levy AD, Sherman PM. Emphysematous infections of the abdomen and pelvis: a pictorial review. Radiographics, 2002; 22 (3): 543-561.

12. Stapleton A. Urinary tract infections in patients with diabetes. Am J Med, 2002; 113 (1A): 80S-84S.

13. Cortés González JR, Ortiz Lara G, Arratia Maqueo JA, Gómez Guerra LS. Irrigación intravesical contínua con amikacina como tratamiento adyuvante en la cistitis enfisematosa. Arch Esp Urol, 2007; 60 (10): 1218-1220.

14. Ronald A, Ludwig E. Urinary tract infections in adults with diabetes. Int J Antimicrob Agents, 2001; 17 (4): 287-292. 